This item was submitted to Loughborough's Research Repository by the author.

Items in Figshare are protected by copyright, with all rights reserved, unless otherwise indicated.

\title{
Lead investors' human capital and fundraising performance: mediating role of reputation
}

PLEASE CITE THE PUBLISHED VERSION

\section{VERSION}

AM (Accepted Manuscript)

LICENCE

CC BY-NC-ND 4.0

\section{REPOSITORY RECORD}

Scholes, Louise, Ye Zhang, Kun Fu, and Mathew Hughes. 2021. "Lead Investors' Human Capital and Fundraising Performance: Mediating Role of Reputation". Loughborough University. 


\title{
Lead investors' Human Capital and Fundraising Performance: Mediating Role of Reputation
}

\begin{abstract}
Equity crowdfunding syndicate emerged in recent years characterised as crowd investors (co-investors) using online platforms to co-invest with other professional investors (lead investors). We investigate the effects of lead investors' general human capital and specialised human capital on their fundraising performance. We also examine the role of reputation in mediating the relationship between human capital and fundraising performance. Result indicates that lead investors' specialised human capital is indeed mediated by their reputation.
\end{abstract}

\section{Key words:}

Crowdfunding; Human capital; Performance; Lead investor; Entrepreneurial Finance

\section{INTRODUCTION}

Equity crowdfunding has grown rapidly in the past few years in the UK and worldwide. In 2017, equity crowdfunding platforms raised $£ 217.7 \mathrm{~m}$ across 360 deals for UK businesses (Beauhurst, 2017), followed by a 15\% increase in deals in 2018-19 (Beauhurst, 2019). Despite the growth of the market, scholars have raised concerns over the information asymmetry problems between entrepreneurs and potential backers (e.g. Cumming, Vanacker, \& Zahra, 2019). On equity 
crowdfunding platforms, entrepreneurs disclose credible information that potential backers use to evaluate the potential of crowdfunding projects, but the crowd of investors normally have difficulties conducting due diligence on crowdfunding projects due to the lack relevant experience, skills, and incentives (Vismara, 2018).

Within this new form of entrepreneurial financing, equity crowdfunding syndicates have emerged in recent years effectively helped reduce the information asymmetry between entrepreneurs and investors by attracting venture capital firms and business angels to the platforms. The syndicates characterized as crowd investors (co-investors) using online platforms such as AngelList and SyndicateRoom to co-invest with professional investors (lead investors) (Wright, Hart \& Fu, 2015), where venture capital firms and business angels form syndicates leveraging various benefits (e.g. Lockett \& Wright, 2001; Wright \& Lockett, 2003; Cumming, Johan, \& Zhang, 2018). Theoretically, equity crowdfunding syndicates combine the best of both worlds: lead investors are incentivised to conduct due diligence and ongoing monitoring and advisory oversight, while the wisdom of crowds infuse greater levels of variability (Cumming, et al., 2019; Nambisan, 2017) to encourage wealth generation.

Human capital has been attributed as a signal to reduce information asymmetries between entrepreneurs and investors and is an important determinant of fundraising performance (Piva \& Rossi-Lamastra, 2018). An equity crowdfunding syndicate diverts the investment activities of crowd investors away from the start-ups and to the lead investors instead, as the reputation of the latter certifies the expected quality of a deal (Agrawal, Catalini, \& Goldfarb, 2016). This changes 
the traditional information asymmetry problem seen in traditional agency models of entrepreneurial finance because it is the quality and credibility of the lead investor that an entrepreneur and a cadre of crowd investors must have trust in. A key portion of the information asymmetry problem, therefore, rests with the lead investor, not solely or strictly with the entrepreneur and nor with the crowd investors (who place their funds and faith in the lead investor). To advance theory on equity crowdfunding syndicates, this study focuses on individual lead investors and investigates how their general human capital (i.e. education and work experience) and specialised human capital (i.e. investment, entrepreneurial, and advisory experience) influences their fundraising performance. Moreover, the study examines the mediating mechanism of reputation through which lead investors' human capital influences their fundraising performance. The conceptual model is shown in

Insert Figure 1 about here

Our study provides two important and timely contributions. First, this study is among the first to theorise and conceptualise the effects of human capital in the under-researched context of equity crowdfunding syndicate and shifts the focus from an entrepreneurs' perspective to an investors' perspective, which is largely neglected in crowdfunding research to date. Second, the majority of crowdfunding studies define and operationalise human capital as education or/and entrepreneurial experience, neglecting other facets of human capital. We provide a detailed 
picture of lead investors' human capital by distinguishing their general human capital and specialised human capital in determining their fundraising performance. Moreover, most entrepreneurial finance studies to date focus on only one type of investor in isolation (Cumming et al., 2019). Equity crowdfunding syndicate provides a platform allows the interplay with different types of investors (Cumming, et al., 2018) and our study provide insights of how the number of co-investors of a lead investor (as a proxy of reputation) influencing the lead investor's fundraising performance by mediating his or her human capital.

\section{THEORETICAL BACKGROUND AND HYPOTHESES}

\section{Human Capital and Information Asymmetry}

Information asymmetry is a common problem in early-stage finance market as investors usually possess incomplete and imperfect information about the prospect of the start-up as compared with the entrepreneur (Courtney, Dutta, \& Li, 2017). This issue is more severe in crowdfunding than in other entrepreneurial financing markets because the crowd of investors normally lack the experience and skills as well as the incentive to conduct due diligence (considering the time and cost involved compared with the amount invested) on crowdfunding projects (Vismara, 2018). Due to the lack of information on assessing the true value of newly founded ventures, investors usually rely on characteristics or resources possessed by start-ups or entrepreneurs act as potent signals of project quality and founder credibility (Courtney et al., 2017). Signals play a crucial role in entrepreneurial finance and typically, an informed party (an entrepreneur) discloses 
information about unobservable characteristics and sends observable signals to the less informed party (investors) to facilitate information exchange (Courtney et al., 2017; Spence, 1973). Described as individuals' attributes such as prior experience, tacit knowledge, and skills (Schultz, 1960), human capital is an important decision factor for venture capitalists and angel investors when make investment decisions (Hsu, Haynie, Simmons, \& McKelvie, 2014). For example, Hsu (2007) finds that founding teams with prior founding experience and a doctoral degree are more likely to be funded. In crowdfunding literature, human capital has been broadly attributed as a signal to reduce information asymmetries between entrepreneurs and investors and is an important determinant of campaign success. Ahlers, Cumming, Günther, and Schweizer (2015) explore the effectiveness of signals used by entrepreneurs and argue that human capital is one of the signals that demonstrates venture quality. Based on an Italian platform SiamoSoci, the study of Piva and Rossi-Lamastra (2018) shows an entrepreneur's business education and previous entrepreneurial experiences influence crowdfunding campaign success.

We follow the established premise in entrepreneurial finance literature that there is a close association between human capital and fundraising performance. However, the majority of entrepreneurial finance literature has focused on entrepreneurs' human capital and only few studies have examined the role of investors' human capital. For example, Collewaert and Manigart (2016) examine how angel investors' human capital affects the valuation of their portfolio companies and Dimov and Shepherd (2005) investigate the relationship between top management teams human capital of VC firms and the firms' performance. To our knowledge, 
the existing crowdfunding literature concentrates on entrepreneurs' human capital and neglect the value of investors' human capital. Due to the different investment mechanisms that equity crowdfunding syndicate shifting the investment focus from backing start-ups/entrepreneurs to backing lead investors, this study takes the perspective of investors and examines instead the human capital of lead investors in association with their fundraising performance. We posit that lead investors with higher level of human capital will have better syndicate fundraising performance. At one hand, lead investor with more human capital will reduce information asymmetries between entrepreneurs and investors by identifying high quality projects and providing professional due diligence on behalf of co-investors. On the other hand, individual lead investors are professional and notable angel investors who cherish their reputation. They publicize their profile including investment history, working experience, investment strategy and plan and so on which effectively help reduce information asymmetry between the lead investor and co-investors.

In the entrepreneurship literature, studies have increasingly distinguished between the general and specific nature of entrepreneurs' human capital (Davidsson \& Honig, 2003; Mosey \& Wright, 2007). In crowdfunding literature, much of the research effort has focused on general human capital represented by education and work experience or entrepreneurial experience as only one aspect of specific human capital. To avoid the omission that oversimplifying the role of human capital in crowdfunding studies, based on the work of Ucbasaran, Westhead and Wright (2008), this article differentiates individual lead investors' general human capital (i.e. education 
and work experience) and specialised human capital (i.e. investment, entrepreneurial, and advisory experience) and provide empirical evidence of individual effects of two types of human capital on fundraising performance.

\section{General Human Capital and Fundraising Performance of Lead Investors}

General human capital relates to skills and knowledge that are easily transferable across different firms (Becker, 1975; Ucbasaran, et al., 2008). Consistent with the study Ucbasaran et al. (2008), we define lead investors' general human capital as a composite of overall education and general work experience.

Representing explicit knowledge (Davidsson \& Honig, 2003), education is valuable in the discovery and exploitation of opportunities and realising the returns from those opportunities (Ucbasaran, et al., 2008). Higher level of education is associated with greater open-mind and receptivity to innovation (Kimberly \& Evanisko, 1981). As a source of knowledge, skills, discipline, motivation and self-confidence (Cooper et al., 1994), it is argued that education provides people with cognitive skills to deal with complex problems and adapt to the changing environment (Hatch \& Dyer, 2004; Ucbasaran et al., 2008). Education is one of the most frequently examined components of human capital and there is considerable debate regarding the relationship between entrepreneurship and education (e.g. Parker, 2006). The empirical findings are mixed in predicting venture creation (Bates, 1990; Evans \& Leighton, 1989), and the exploitation of entrepreneurial opportunities (Davidsson \& Honig, 2003). Lead investors with 
higher level of education will more likely to leverage their knowledge and skills obtained from education to identify and exploit syndicate investment opportunities (Shane, 2000; Ucbasaran et al., 2008). Like all the kinds of entrepreneurial financing, the environmental condition of crowdfunding is continuously changing. Therefore, the success of leading a syndicate investment requires lead investors to keep learning and flexibility to assess the changing situations (Collewaert \& Manigart, 2016). Highly educated lead investors possess a broader knowledge base and are generally better informed. However, lead investors with lower level of education have narrower knowledge and fewer skills and take long time to assimilate new knowledge in a meaningful way (Collewaert \& Manigart, 2016).

We use the term general work experience to differentiate the experience that specific to a particular task, such as running a business venture (i.e. entrepreneurial experience). General work experience does not relate to current syndicate investment task of lead investors, but refers to their overall employment experience in any field. General work experience is another aspect of general human capital that may lead to knowledge and skills and has been frequently operationalised by total years of work experience (e.g. Davidsson \& Honig, 2003). However, this indicator may provide limited information about the nature of the skills and knowledge acquired (Ucbasaran, et al., 2008). As most of crowdfunding projects are in emerging industries, lead investors' recognition of syndicate investment opportunities is guided by their ability to accumulate new knowledge (Dimov \& Shepherd, 2005), which is, in turn, dependent upon their existing stock of knowledge (Cohen \& Levinthal, 1990). We believe that lead investors acquire 
knowledge and skills from breadth of different work experiences, thus the number of prior full-time jobs should be a better measure of general work experience (Ucbasaran, et al., 2008). The broader a lead investor's general work experience, they would have accumulated more diverse knowledge and networks and learnt more about opportunities through participation in different markets (Casson, 1982). Lead investors access to different types of information from various market, which is needed for opportunity identification and pursuit (Ucbasaran, et al., 2008).

General human capital assists the integration and accumulation of new knowledge, which provides lead investors with larger opportunity sets (Gimeno, Folta, Cooper, \& Woo, 1997) and the adaption to situations of greater uncertainty. Lead investors with higher level of general human capital will be more capable to source and bring high-quality projects to the platform, reducing the information asymmetries between co-investors and entrepreneurs. Moreover, they will be more convincing to potential co-investors to have trust in their abilities, reducing the uncertainty and information asymmetries faced by co-investors, which drives better fundraising performance. In contrast, lead investors with lower level of general human capital would search for divergent information and knowledge, which may increase communication cost with potential co-investors and entrepreneurs (Vissa \& Chacar, 2009). Therefore, we propose that the following hypothesis:

Hypothesis 1: Lead investors' general human capital is positively related to their syndicate fundraising performance. 


\section{Specialised Human Capital and Fundraising Performance of Lead Investors}

Specific human capital relates to skills and experience that are less transferable and have a limited scope of applicability such as within a firm or for a particular task or context (Becker, 1975; Ucbasaran, et al., 2008). We believe the more specific components of lead investors' human capital (i.e. more closely related to the crowdfunding syndicate context), the more proximate to predict their fundraising performance (Dimov, 2010). Research shows specific human capital of entrepreneurs such as industry knowledge and entrepreneurial experience are among the most important selection criteria by venture capitalists and angel investors (Levie \& Gimmon, 2008; Zacharakis \& Meyer, 2000). Lead investors recognise and exploit syndicate investment opportunities by leveraging experience to lead investments on platforms. Therefore, this study conceptualise lead investors' syndicate investment-specific human capital as specialised human capital, which is a composite human capital consisting of investment experience, entrepreneurial experience and advisory experience.

Investment experience is the former experience of the lead investor with investing a new venture themselves. Crowdfunding platforms like AngelList maintain records of projects lead investors' invested before. Such records are observable to potential co-investors. Using the number of previous investments, Eder (2015) finds lead investor's investment experience explains approximately $40 \%$ of the variation in total funding and the number of backers of a lead investor. Cumming and Zhang (2016) find that due diligence provided by crowdfunding platforms is associated with higher funds raised. Within syndicate structure, lead investors take 
over such responsibility. Investment experience can be a credible signal of lead investor's capability because they may become more accurate in choosing and bringing the "right" projects to the platform as their investment experience increase because they utilize superior decision processes relative to those with less experience (Shepherd, Zacharakis, \& Baron, 2003). Experienced lead investors could also group domain-specific knowledge from previous investment experience and enables them to better evaluate investment opportunities (Mitteness, Baucus, \& Sudek, 2012). Individuals tend to become increasingly efficient when become more experienced with respect to a particular task (Shepherd, et al., 2003). We believe lead investors with prior investment experience should have learned skills and knowledge necessary for the investment of new ventures through trial and error, which is a learning process less likely to be obtained through formal education or other work experiences (Zarutskie, 2010). They will have a better understanding of which start-ups to invest, how to better access to these companies as well as how to actively manage those investments (Zarutskie, 2010).

Entrepreneurial experience is the former experience of the lead investor with founding a new venture themselves. It is human capital that could provide considerable expertise and knowledge on what is important, how to do things and contacts (Stuart \& Abetti, 1990). In the entrepreneurship literature, evidence shows that entrepreneurial experience has positive effects on various entrepreneurial outcomes such as venture performance, external funding and profitability. Entrepreneurial experience adds to specialised human capital by providing valuable resources including skills, direct learning and knowledge about the entrepreneurial process. (Mosey \& 
Wright, 2007). Previous entrepreneurial experience provides lessons for the entrepreneur to understand how to attract customers, suppliers and other stakeholders in the business (Bruderl, Preisendorfer, \& Ziegler, 1992). Furthermore, Dimov (2010) argues that more experienced entrepreneurs will develop higher their ability to act in the context of missing information. Lead investors are responsible for conducting due-diligence and screening for potential projects when choosing in which start-ups to invest. Lead investors with more entrepreneurial experience are equipped with more skills and knowledge in start-up process know-how. The "know-how" of founding a start-up likely leads to more accurate and detailed assessment of an investment opportunity required as part of due diligence. Prior entrepreneurial experience enables lead investors critically analyse business plans provided by start-ups and find holes in their business models and (Dimov \& Shepherd, 2005).

Drawing from a socio-cognitive perspective, scholars address that individuals with prior experience could develop more complex knowledge structures, which leads to more efficient information processing and more accurate predictions (Stabell, 1978; Westphal \& Fredrickson, 2001) . It also suggests that prior experience yields causal depth of knowledge and coherent knowledge on how to exercise a set of routines (Nelson \& Winter, 1982). Previous advisory experience generates management know-how, which may affect the venture performance through more promising strategies or better management methods (Cooper, Gimeno-gascon, \& Woo, 1994). Bellavitis, Filatotchev, \& Souitaris (2017) find that venture capital firms having top advisors increases the number of exits. Advisory experience provides them with capabilities of 
analysing business plans, implementing more promising business strategies and management methods, which could provide added-value to funded ventures. Current and past advisory experiences could shape individual's thinking and perceptions and equip them with specific skills and knowledge about how ventures operate (Kor \& Sundaramurthy, 2009). We believe lead investors with these skills and knowledge of organisation will enhance their capabilities of providing monitor and advising roles to funded ventures. With an analysis of 541 equity crowdfunded projects on Crowdcube, Ralcheva and Roosenboom (2016) find that ventures appointed advisory board/professional advisors is positively associated with crowdfunding success (Ralcheva \& Roosenboom 2016). In the same vein, it is expected that lead investors taking more advisory roles should have better fundraising performance.

As we have discussed, specialised human capital can provide a lead investor with the knowledge of investment opportunities recognition and evaluation, start-up process know-how and management know-how. Lead investors with higher level of specialised human capital will have a better understanding of target ventures and entrepreneurs and will conduct due diligence in a more professional way, thus reducing the information asymmetries between co-investors and entrepreneurs. Furthermore, lead investors could integrate syndicate investment-specific knowledge and skills in more meaningful way and apply the specific problem-solving procedures they have developed over time to syndicate projects they led (Collewaert \& Manigart, 2016). The higher level of specialised human capital, potential co-investors will have more confidence in the veracity of the lead investor, reducing information asymmetry between the lead investor and 
co-investors, leading to better fundraising performance. Therefore, we expect that:

Hypothesis 2: Lead investors' specialised human capital is positively related to their syndicate fundraising performance.

\section{Potential Mediation Effect of Reputation}

We have argued that lead investors' general human capital and specialised human capital will enhance their fundraising performance. Despite the theoretical rationale in hypotheses 1 and 2, we suggest that the degree of the performance may be contingent on reputation as human capital tends to establish lead investors' reputation on the equity crowdfunding platform. The majority crowdfunding campaigns are a one-off process for the entrepreneur. However, as professional investors, lead investors usually raise multiple funds and thus they are concerned about their reputation if they would like to keep active in crowdfunding syndicate investment. Reputation provides information about an individual's ability (Shane \& Cable, 2002), containing informational properties such as network status within the industry (Plagmann \& Lutz, 2019) that can signal the quality of a lead investor to potential entrepreneurs and co-investors.

We believe the reputation of lead investors is an important consideration for ventures seeking funds. Entrepreneurs are tend to cooperate with lead investors with good reputation in the market because lead investors are considered as "smart money" (Mason, 2006), providing not only funding but also added value to ventures. As there is absent of credible and adequate information about the ventures, potential co-investors tend to rely on the reputation of lead 
investors as certification of expected quality of a deal (Agrawal, et al., 2016). For co-investors, lead investors with good reputation will have more advantages when negotiate with entrepreneurs about deal size and other investment conditions. They could identify and select more promising syndicate investment opportunities and then bring to the platform. Lead investors with good reputation could develop better working relationships with entrepreneurs (Nahata, 2008) and reduce the information asymmetries faced by potential co-investors, and thus attract more co-investors join the syndicate. Therefore, we argue that lead investors' reputation on the crowdfunding syndicate platform is one of the key drivers for their fundraising success.

We believe lead investors' general human capital plays a role in acquiring reputation on the syndicate platform. Taking a bridging role between co-investors and entrepreneurs, lead investors with higher level of general human capital could develop more complex knowledge structures, which leads to more efficient information processing (Stabell, 1978; Westphal \& Fredrickson 2001). General human capital equips lead investors the capability to share their views and values more effectively and efficiently through the platform. Therefore, lead investors with a higher level of general human capital can better communicate with both parties, reducing the communication cost (Vissa \& Chacar, 2009). Moreover, they have accumulated more diverse knowledge and networks acquired from education and various work experience and thus will be more efficient to establish their reputation on the platform. Therefore, we propose that the following hypothesis:

Hypothesis 3: Lead investors' reputation on the syndicate platform mediates the effect of 
general human capital on their syndicate fundraising performance.

A lead investor's reputation is diligently built upon experience (Nahata, 2008). Lead investors with more experience are equipped with expertise specific to syndicate investment context, from identifying investment opportunity, negotiating with entrepreneurs, to conducting due diligence. Investment track records are observable on platforms, sending signals to potential co-investors about lead investors' credibility. Lead investors with higher level of specialised human capital are equipped with syndicate investment-specific knowledge and skills, which could broad their social network size (Shane \& Khurana, 2003) and enhance the effectiveness of network development (Mosey \& Wright, 2007). These networks will in turn facilitate lead investors to obtain more diverse resources and information (Hsu, 2007). They could leverage the resources and information acquired to pursue more valuable and powerful relationships on the platform. Therefore, they will be more likely to establish positive reputation on the platform. Lead investors who have lower level of specialised human capital have less available track record for entrepreneurs and potential co-investors to infer their quality (Hsu, 2007). They may make extra efforts and time to signal their quality (Spence, 1974) and takes long to build their reputation on the platform. Therefore, we propose that the following hypothesis:

Hypothesis 4: Lead investors' reputation on the syndicate platform mediates the effect of specialised human capital on their syndicate fundraising performance. 


\section{METHOD}

\section{Data and Sample}

The study draws on two sources of data: the syndicate platform AngelList and professional social network LinkedIn. We use AngelList as primary data sources and have collected the information of 178 individual lead investors over the period of June 2013 to May 2018 to test our hypotheses. AngelList provides lead investors' data of gender, location, investment experience, advisory experience, reputation and the fundraising performance. LinkedIn provides data of education, general work experience and entrepreneurial experience of lead investors.

Established in 2010, AngelList is a world-leading syndicate platform in the U.S. It launched the first online syndicate in 2013. Individual accredited investors such as angel investors and institutions including venture capital funds, angel groups and accelerator firms on the platform can form syndicates (Agrawal et al., 2016). In line with the study of Agrawal et al. (2016), we exclude institutional lead investors and only focus on individual lead investors. In this study, we define lead investors as experienced angel investors who leading source investments, conducting due diligence, and securing allocation. Data on AngelList are publicly available and updated actively and regularly by participants. As a comprehensive database, AngelList provides detailed biography of investors and entrepreneurs. 


\section{Variables and Measures}

\section{Dependent Variable.}

Fundraising performance of lead investors. The dependent variable of this study is the fundraising performance of lead investors. Total funding amount is a common measure of performance in crowdfunding studies (e.g. Ahlers et al., 2015). We use the total amount that the lead investor's syndicate backed on AngelList to measure the fundraising performance of lead investor.

\section{Independent Variables.}

General human capital. We use the equally-weighting method (Florin \& Lubatkin 2003; Stam \& Elfring, 2008) and operationalise general human capital by taking the sum of education (z-standardised) and general work experience (z-standardised) of lead investors. 1) Education. We coded the highest degree of lead investors, ranked highest from $\mathrm{PhD}$ to lowest diploma and under. Specifically, $\mathrm{PhD}=4$, Master=3, Bachelor=2, Diploma and below=1. 2) General work experience. Consistent with the study of Ucbasaran, et al., (2008), we use the number of organisations worked as a measure for lead investors' general work experience, captured on the lead investor's LinkedIn profile.

Specialised human capital. Specialised human capital is a multi-item construct including investment experience, entrepreneurial experience and advisory experience of lead investors. Following existing studies (Florin \& Lubatkin 2003; Stam \& Elfring 2008), we use the 
equally-weighting method and sum the three measures to operationalise the specialised human capital. We z-standardised them before taking the sum of the three measures. 1) Investment experience is measured as the number of ventures invested by a lead investor, counted as the number of venture's logo shown on the investment profile of the lead investor posted on AngelList. 2) Entrepreneurial experience. In line with the study of Hsu (2007), we code number of ventures founded and co-founded as a measurement of entrepreneurial experience of lead investor, shown on the lead investor's LinkedIn profile. 3) Advisory experience is measured by the number of advisor roles played by lead investors. We counted the number shown personal profile of lead investor on AngelList.

\section{Mediator.}

Reputation. We use the number of unique LPs (limited partners as co-investors) who have invested into the lead investor's syndicate deals on AngelList as a measure of the lead investor's reputation on the platform. LPs co-invest with the lead investor and often experts in a specific market and can provide value-added advisory to deals syndicated by lead investors. The number of unique LPs of a lead investor reflects his or her ability to attract potential co-investors and the network status on the platform.

\section{Control variables.}

This study includes two control variables to rule out alternative explanations of our model and provide more accurate estimates of our hypothesised variables. 
Gender. This dummy variable shows whether the lead investor was male. Male $=1$, female $=0$. Literature finds that female entrepreneurs raised less money than males (Vismara, 2016). Therefore, we control gender to rule out this influence on fundraising performance of lead investors.

Location. This dummy variable shows whether the location of lead investor is in San Francisco. San Francisco=1, other location=0 if the lead investor lives elsewhere. It has been found that transactions in crowdfunding market are more likely to occur between investors and entrepreneurs in the same geographical area (Lin \& Viswanathan 2016). As most of ventures seeking for funds on AngelList are from San Francisco and the platform AngelList locates in San Francisco as well, we assume the location of lead investors will influence their fundraising performance.

\section{RESULTS}

\section{Descriptive Statistics}

Table 1 shows the descriptive statistics of our data. On average, syndicates of lead investors in the sample raised $\$ 726,966$ on AngelList. $95.5 \%$ of lead investors are male, with a standard deviation of $0.21 .43 .3 \%$ of them live in San Francisco. On average, the number of unique LPs on AngelList is 65 .

Insert Table 1 about here 
In Table 2 we provide correlations matrix for the variables used in this study. We standardised variables of general human capital, specialised human capital and the mediator reputation by subtracting the mean and dividing by the standard deviation. To ensure that multicollinearity was not a problem, we conducted a variance information factor (VIF) test for all variables employed in our subsequent analyses. The average VIF is 1.12 (below the conventional threshold of 6), and the maximum VIF is 1.25 (below the conventional threshold of 10 , McDonald \& Moffit, 1980). Thus, we conclude that multicollinearity does not appear to be a problem in our estimates.

Insert Table 2 about here

\section{Total Effects and Direct Effects}

Table 3 presents the results of the regression analysis. Five models were estimated. Model 1 is a base model and includes only the control variables. The dummy variables gender and location of lead investors do not appear to be associated with their fundraising performance.

Model 2 adds to the control variables the independent variable general human capital. It shows general human capital has no significant effect on fundraising performance of lead investors without taking into account the effect of specialised human capital. Model 3 adds the 
independent variable specialised human capital. The result shows that without the effect of general human capital, specialised human capital is positively associated with fundraising performance of lead investors $(\beta=0.62, \mathrm{p}<0.01)$. In Model 4 , both independent variables general human capital and specialised human capital are added. It shows the total effects of general human capital and specialised human capital on lead investors' fundraising performance. The result illustrates that specialised human capital of lead investors is positively associated with their fundraising performance $(\beta=0.626, \mathrm{p}<0.01)$ in the absence of the mediator reputation. However, we found that general human capital has no significant effect on fundraising performance of lead investors.

We test our Hypotheses 1 and 2 in Model 5, which shows the direct effects of general human capital and specialised human capital on lead investors' fundraising performance. As shown in Table 3, both general human capital and specialised human capital have no direct fundraising performance of lead investors. Therefore, Hypothesis 1 and Hypothesis 2 are rejected. Consistent with our arguments, we find the coefficient of reputation is positive and significant at the $p<0.001$ level, suggesting that lead investors with a higher level of reputation on the platform will enhance their fundraising performance, others things being equal.

Insert Table 3 about here 


\section{Mediation (indirect) Effect}

Hypotheses 3 and 4 suggest that lead investors' reputation mediates the effects of general human capital and specialised human capital on fundraising performance. The mediation effect occurs when (1) the independent variable is significantly affects the mediator; (2) the independent variable significantly affects the dependent variable in the absence of the mediator. (3) the mediator has a significant effect on the dependent variable; and (4) the effect of the independent variable in the presence of the mediator is zero or reduced (Baron and Kenney, 1986; Dimov, 2010). The analyses in Table 3 confirm conditions (2), (3) and (4) for specialised human capital but rule out general human capital. Therefore, Hypothesis 3 is not supported. Table 4 shows the effect of specialised human capital is positive and significant associated with the mediator reputation, suggesting that mediation condition (1) is also met for specialised human capital.

Insert Table 4 about here

In order to test the significance of the mediation effects, we conduct Sobel tests (Baron \& Kenny, 1986; MacKinnon \& Dwyer, 1993; Sobel, 1982). The ratio of the indirect effect over its standard error is referred to as the Sobel statistic, which is compared to a $\mathrm{z}$ distribution to determine the statistical significance of the indirect effect (Sobel, 1982). For full mediation, the 
Sobel test z-value must exceed 1.645 for 5 percent significance and the effect ratio should exceed 0.8; for partial mediation, the Sobel test Z-value must exceed 1.645 and the effect ratio be lower than 0.8 (Ndofor, Sirmon, \& He, 2011). Table 5 provides Sobel statistics associated with the indirect effects of lead investors' general human capital and specialised human capital on their fundraising performance. Supporting Hypothesis 4, the Sobel test indicates that the indirect effect of specialised human capital on fundraising performance $(\mathrm{z}=2.777, \mathrm{p}<0.001)$ was in the anticipated direction and statistically significant. It is consistent with the presented arguments that specialised human capital can lead investors establish their reputation on the platform, but it is the reputation that in turn determines lead investors' fundraising performance.

Insert Table 5 about here

\section{Robustness Check}

In the analysis we reported above, we use the number of unique LPs/co-investors who have invested into the syndicate's deals on AngelList to measure lead investor's reputation. We substitute the current measure of reputation and use the number of references received by lead investors on AngelList as an additional robustness check. As illustrated in model 5 of Table 6, both general human capital and specialised human capital have no significant effects on lead investors' fundraising performance. Therefore, both Hypotheses 1 and 2 are rejected. The results are consistent with our 
preliminary ones. For the mediation effect of reputation, as reported in the previous section, it occurs when meets the four conditions. As reported in Table 6 and 7, the general human capital satisfies none of the four conditions. Therefore, Hypothesis 3 is not supported. The analyses in Table 6 confirm conditions (2), (3) and (4) for specialised human capital. Table 7 shows the effect of specialised human capital is positive and significant associated with the mediator reputation, suggesting that mediation condition (1) is also met for specialised human capital. Therefore, Hypotheses 4 is supported. The results are in line with our preliminary analysis.

\section{DISCUSSION}

This study aims to advance theory in the under-researched context equity crowdfunding syndicate. Utilising human capital theory, we examined the direct impacts of general human capital and specialised human capital on fundraising performance of lead investors respectively. Moreover, we investigated whether reputation on the syndicate platform mediates the two relationships.

Our first contribution is to conceptualise the effects of human capital in equity crowdfunding syndicate and shifts the focus from an entrepreneur's perspective to an investor's perspective, which is neglect in crowdfunding literature. As equity crowdfunding syndicate diverts crowd investors' main investment activities from the start-ups the lead investors, it provides an ideal context to investigate impact of human capital from investor's perspective.

In doing so, we distinguished lead investors' human capital into general human capital (i.e. 
education and general work experience) and specialised human capital (i.e. investment, entrepreneurial and advisory experience) and investigated the effects on fundraising performance respectively. Our second contribution is that we extend the human capital theory in crowdfunding studies by providing the more comprehensive portrait of human capital. We did not find the direct effects of general human capital and specialised human capital on fundraising performance of lead investors. Therefore, we address that human capital is not an effective and direct signal that could be received by crowd investors.

According to Becker (1964), human capital investments such as education and work experience are different from knowledge and skills, which are theoretically the result or outcome of human capital investments. An explanation of the non-significant results is that human capital investments (education/work experience) may not lead to the acquisition of knowledge and skills (Unger, Rauch, Frese, \& Rosenbusch, 2011) and the latter depends on characteristics of the person and the environment (Unger et al., 2011). Therefore, human capital investments are indirect indicators of human capital and may not directly signal lead investors quality and credibility. Another explanation is that lead investors with higher levels of general and specialised human capital pursue more syndicate investment opportunities that take longer time to develop to evident better fundraising performance.

For general human capital, lead investors may not able to acquire syndicate investment related knowledge and skills from their degree per se. What an individual has been learned from education may depend on characteristics of the school including types of school such as business 
school, the teaching quality (Unger et al., 2011) and one's absorptive capability. Moreover, diverse general work experience may not lead to the enrichment of knowledge and skills that could be applied directly in syndicate investment. Lead investors with broader general work experience will obtain diverse information and social network. Lead investors may not able to leverage the various sources of information to be used into syndicate-leading activities.

For specialised human capital, past experience may not trigger the process of effective learning, which leads to acquisition of knowledge and skills from experience. As argue by Reuber and Fisher (1999), any specific knowledge is likely to have a decreasing shelf life in rapidly changing environments. Moreover, experience per se does not lead to knowledge and several potentially important theoretical moderators of the human capital-performance relationship (Unger et al., 2011). For example, individual differences or the richness of the learning environments may have an impact (Reuber \& Fisher, 1999).

Our third contribution is to provide insights of how lead investors' reputation on the platform mediates the effects of human capital on fundraising performance. As we expected, reputation mediates the relationship between specialised human capital and fundraising performance of lead investors. This also provides an alternative explanation of the non-significant direct effect of specialised human capital, which enhances the fundraising performance of lead investors only in conjunction with adequate levels of reputation, the effect of which turns to increase performance. We also find reputation does not mediates the effect of general human capital on fundraising performance. One of the possible reason could be that although lead 
investors accumulated diverse knowledge and skills from higher education and broader work experience, they may not directly be useful in establishing reputation on the platform. The crowd of investors may trust more for lead investors with diverse specialised human capital, which is more directly related to syndicate-leading activities.

\section{Limitations and Future Research}

Our study has some limitations that give rise to opportunities for further research. Firstly, this study focuses on angel investors as lead investors. Future study will investigate institutional lead investors as well and make comparison between the two different types of lead investors. Future studies will also investigate how lead investors and and entrepreneurs interact to create value and to minimize the potential principal-principal problems (Cumming et al., 2019). Secondly, this study treats both general human capital and specialised human capital as multi-item constructs. In the future study, we will investigate the each dimension's individual effect on lead investors' fundraising performance. Future studies will also take into consider factors such as lead investors' characteristics that could potentially moderates the relationship between human capital and performance.

\section{CONCLUSION}

This paper is the first to conduct theoretical arguments and empirical examinations of the effectiveness of general human capital and specialised human capital that lead investors possess to enhance their fundraing performance in an equity crowdfunding context, from an investor's 
perspective. It also demonstrates how reputation on the syndicate platform mediates the relationship between human capital and fundraising performance of lead investors. It finds that both lead investors' general human capital and specialised human capital have no direct effect on their fundraising performance. Human capital investments such as education and experience may not transfer to knowledge and skills needed by syndicate-leading activities. However, the mechanism of of specialised human capital on fundraising performance could be mediated by reputation, which is a more direct effective signal that could be received by co-investors and entrepreneurs, leading to better performance. This study contributes to the current debate on the role of human capital in crowdfunding and more generally in entrepreneurial financing. 


\section{REFERENCES}

Agrawal, A., Catalini, C., \& Goldfarb, A. 2016. Are Syndicates the Killer App of Equity Crowdfunding? California Management Review, 58(2): 111-124.

Ahlers, G. K. C., Cumming, D., Günther, C., \& Schweizer, D. 2015. Signaling in equity crowdfunding. Entrepreneurship Theory and Practice, 39(4): 955-980.

Baron, R. \& Kenney, D. 1986. The moderator-mediator variable distinction in social psychological research: conceptual, strategic, and statistical consideration. Journal of Personality and Social Psychology, 51(6): 1173-82.

Bates, T. 1990. Entrepreneur human capital inputs and small business longevity, Review of Economics and Statistics, 72: 551-559.

Beauhurst. 2017. The Deal: Equity investment in the UK 2017. London: Beauhurst.

Beauhurst. 2019. The Deal: Equity investment in the UK 2019. London: Beauhurst.

Becker, G. S. 1964. Human Capital: A Theoretical and Empirical Analysis, with Special Reference to Education. New York: National Bureau of Economic Research \& Columbia University Press.

Becker, G. S. 1975. Human Capital. Chicago, IL: Chicago University Press.

Bellavitis, C., Filatotchev, I., \& Souitaris, V. 2017. The Impact of Investment Networks on Venture Capital Firm Performance: A Contingency Framework. British Journal of Management, 28(1): $102-119$.

Bruderl, J., Preisendorfer, P., \& Ziegler, R. 1992. Survival Chances of Newly Founded Business Organisations. American Sociological Review, 57(2): 227-242.

Casson, M. 1982. The entrepreneur: An economic theory. Totowa, NJ: Barnes \& Noble.

Cohen, W. M. \& Levinthal D. A. 1989. Innovation and learning: the two faces of R\&D. Economic Journal, 99(397): 569-596.

Collewaert, V., \& Manigart, S. 2016. Valuation of angel-backed companies: The role of investor human capital. Journal of Small Business Management, 54(1): 356-372.

Cooper, A.C., Gimeno-Gascon, F.J., Woo, C.Y. 1994. Initial human capital and financial capital as predictors of new venture performance. Journal of Business Venturing, 9(5): 371-396.

Courtney, C., Dutta, S., \& Li, Y. 2017. Resolving Information Asymmetry: Signaling, Endorsement, and Crowdfunding Success. Entrepreneurship: Theory and Practice, 41(2): 265-290. Cumming, D., Johan, S., \& Zhang, Y. 2018. Public policy towards entrepreneurial 
finance: spillovers and the scale-up gap. Oxford Review of Economic Policy, 34(4): 652675.

Cumming, D., Vanacker, T., \& Zahra, S. 2019. Equity crowdfunding and governance: toward an integrative model and research agenda. Academy of Management Perspectives forthcoming.

Cummings, M. E., Rawhouser, H., Vismara, S., \& Hamilton, E. L. 2019. An equity crowdfunding research agenda: evidence from stakeholder participation in the rulemaking process. Small Business Economics, 54(4): 907-932.

Davidsson, P., \& Honig, B. 2003. The role of social and human capital among nascent entrepreneurs. Journal of Business Venturing, 18(3): 301-331.

Dimov, D., \& Shepherd, D. A. 2005. Human capital theory and venture capital firms: Exploring "home runs" and "strike outs." Journal of Business Venturing, 20(1): 1-21.

Dimov, D. 2010. Nascent entrepreneurs and venture emergence: Opportunity confidence, human capital, and early planning. Journal of Management Studies, 47(6): 1123-1153.

Eder, S. 2015. A Taxonomy of Online Syndicates (Master's Thesis, Sloan School of Management). http://dspace.mit.edu/handle/1721.1/7582

Evans, D.S., \& Leighton, L.S. 1989. Some empirical aspects of entrepreneurship. American Economic Review, 79(3): 519-535.

Florin, J., Lubatkin, M., \& Schulze, W., 2003. A social capital model of high growth ventures. Academy of Management Journal, 46(3): 374-384.

Gimeno, J., Folta, T.B., Cooper, A.C. \& Woo C.Y. 1997. Survival of the Fittest? Entrepreneurial Human Capital and the Persistence of Underperforming Firms. Administrative Science Quarterly, 42: 750-783.

Hatch, N. W., \& Dyer, J. H. 2004. Human capital and learning as a source of sustainable competitive advantage. Strategic Management Journal, 25(12): 1155-1178.

Hsu, D. H. 2007. Experienced entrepreneurial founders, organisational capital, and venture capital funding. Research Policy, 36(5): 722-741.

Hsu, D. K., Haynie, J. M., Simmons, S. A., \& McKelvie, A. 2014. What matters, matters differently: a conjoint analysis of the decision policies of angel and venture capital investors. Venture Capital, 16(1): 1-25.

Kimberly, J. \& Evanisko, M. 1981. Organisational innovation: The influence of individual, organisational, and contextual factors on hospital adoption of technological and administrative innovations. Academy of Management Journal, 24: 689-713. 
Kor, Y. Y., \& Sundaramurthy, C. 2009. Experience-based human capital and social capital of outside directors. Journal of Management, 35(4): 981-1006.

Levie, J., \& Gimmon, E. 2008. Mixed signals: Why investors may misjudge first time high technology venture founders. Venture Capital, 10(3): 233-256.

Lin, M., \& Viswanathan, S. 2016. Home Bias in Online Investments: An Empirical Study of an Online Crowdfunding Market. Management Science, 62(5): 1393-1414.

Lockett, A., \& Wright, M. 2001. The syndication of venture capital investments. OMEGA: The International Journal of Management Science,29(5): 375-390.

MacKinnon, D. P., \& Dwyer, J. H. 1993. Estimating mediated effects in prevention studies. Evaluation Review, 17(2): 144-158.

Mason, C. 2006. Informal Sources of Venture Finance. In S. Parker (Ed), The Life Cycle of Entrepreneurial Ventures: 259-299. New York: Springer.

McDonald, J.F. \& Moffitt, R.A. 1980. The uses of tobit analysis. The Review of Economics and Statistics, 62(2): 318-321.

Mitteness, C., Baucus, M. \& Sudek, R. 2012. Horse vs. Jockey? How stage of funding process and industry experience affect the evaluations of angel investors. Venture Capital, 14(4): 241267.

Mosey, S., \& Wright, M. 2007. From human capital to social capital: A longitudinal study of technology-based academic entrepreneurs. Entrepreneurship: Theory and Practice, 31(6): 909-935.

Nahata, R. 2008. Venture capital reputation and investment performance. Journal of Financial Economics, 90(2): 127-151.

Nambisan, S. 2017. Digital entrepreneurship: Toward a digital technology perspective of entrepreneurship. Entrepreneurship Theory and Practice, 41(6): 1029-1055.

Nelson R.R., \& Winter, S.G. 1982. An Evolutionary Theory of Economic Change. Harvard University Press: Cambridge, MA.

Ndofor H.A., Sirmon, D.G. \&, He, X. 2011. Firm resources, competitive actions and performance: investigating a mediated model with evidence from the in-vitro diagnostics industry. Strategic Management Journal, 32(6): 640-657.

Parker, S. C. 2006. Entrepreneurship, Self-employment and the Labour Market. In A. Baus, et al. (Eds.) Oxford Handbook of Entrepreneurship, Oxford: OUP. 
Piva, E., \& Rossi-Lamastra, C. 2018. Human capital signals and entrepreneurs' success in equity crowdfunding. Small Business Economics, 51(3): 667-686.

Plagmann, C., \& Lutz, E. 2019. Beggars or choosers? Lead venture capitalists and the impact of reputation on syndicate partner selection in international settings. Journal of Banking and Finance, 100: 359-378.

Ralcheva, A., \& Roosenboom, P. 2016, May. The role of certification for equity crowdfunding success. Paper presents at the 33rd International Conference of the French Finance Association, Liège.

Reuber, A.R., \& Fisher, E. 1999. Understanding the consequences of founders' experience. Journal of Small Business Management, 37: 30-45.

Schultz, T. W. 1960. Capital formation by education. Journal of Political Economy, 68(6): 571583.

Shane, S. (2000). Prior knowledge and the discovery of entrepreneurial opportunities. Organization Science, 11: 448-469.

Shane, S., \& Cable, D. 2002. Network Ties, Reputation, and the Financing of New Ventures. Management Science, 48(3): 364-381.

Shane, S., \& Khurana, R. 2003. Bringing individuals back in: the effects of career experience on new firm founding. Industrial and Corporate Change, 12(3): 519-543.

Sobel, M.E. 1982. Asymptotic confidence intervals for indirect effects in structural equation models. Sociological Methodology, 13(1982): 290-312.

Spence, A. M. 1973. Job market signaling. The Quarterly Journal of Economics, 87(3): 355374.

Stabell CB. 1978. Integrative complexity of information environment perception and information use: an empirical investigation. Organization Behavior and Human Performance, 22: 116142.

Stam, W., \& Elfring, T. 2008. Entrepreneurial orientation and new venture performance: The moderating role of intra-and extraindustry social capital. Academy of Management Journal, 51(1): 97-111.

Stuart, R. W., \& Abetti, P. A. 1990. Impact of entrepreneurial and management experience on early performance. Journal of Business Venturing, 5(3): 151-162.

Ucbasaran, D., Westhead, P., \& Wright, M. 2008. Opportunity identification and pursuit: does an entrepreneur's human capital matter?. Small Business Economics, 30(2): 153-173. 
Unger, J., Rauch, A., Frese, M., \& Rosenbusch, N. 2011. Human capital and entrepreneurial success: A meta-analytical review. Journal of Business Venturing, 26(3): 341-358.

Vismara S. 2018. Signaling to Overcome Inefficiencies in Crowdfunding Markets. In Cumming D., \& Hornuf L. (Eds), The Economics of Crowdfunding: 29-56. Cham: Palgrave Macmillan.

Vismara, S. 2016. Equity retention and social network theory in equity crowdfunding. Small Business Economics, 46(4): 579-590.

Vissa, B., \& Chacar, A. S. 2009. Leveraging ties: the contingent value of entrepreneurial teams' external advice networks on Indian software venture performance. Strategic Management Journal, 30(11): 1179-1191.

Westphal, J. D., \& Fredrickson, J. W. 2001. Who directs strategic change? Director experience, the selection of new CEOs, and change in corporate strategy. Strategic Management Journal, 22(12): 1113-1137.

Wright, M., Hart, M. \& Fu, K. 2015. A Nation of Angels: Assessing the Impact of Angel Investing Across the UK. https://hdl.handle.net/2134/12200363.v1

Zacharakis, A., \& Meyer, G. D. 2000. The potential of actuarial decision models: Can they improve the venture capital investment decision? Smart Port Perspectives: Essays in Honour of Hans Smits, 15(4): 323-346.

Zarutskie, R. 2010. The role of top management team human capital in venture capital markets: Evidence from first-time funds. Journal of Business Venturing, 25(1): 155-172. 
APPENDIX

Figure 1

Conceptual model

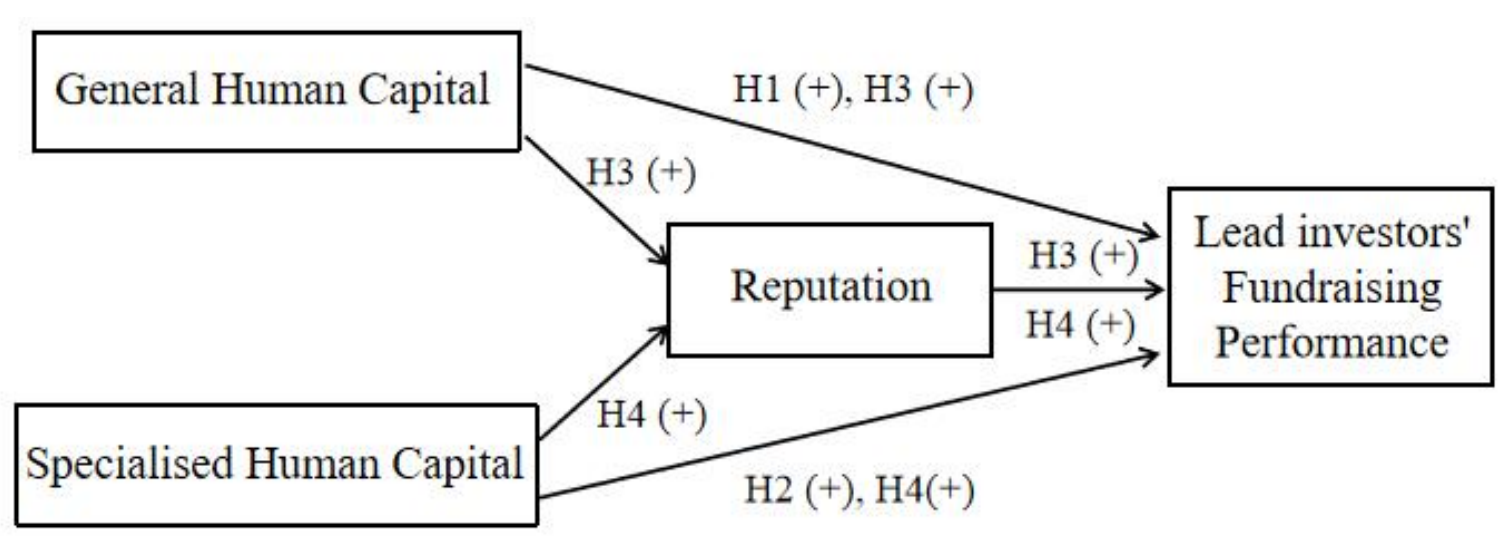


TABLE 1

Variables description and summary statistics

\begin{tabular}{|l|l|l|l|l|l|l|}
\hline Variable & Obs & Mean & SD & Min & Max & Variable description \\
\hline Gender & 178 & 0.955 & 0.208 & 0 & 1 & Dummy=1 if the lead investor is male; 0 otherwise \\
\hline Location & 178 & 0.433 & 0.497 & 0 & 1 & $\begin{array}{l}\text { Dummy=1 if the lead investor lives in San } \\
\text { Francisco; 0 otherwise }\end{array}$ \\
\hline General Human Capital & 178 & -0.014 & 1.389 & -4.109 & 4.667 & $\begin{array}{l}\text { Sum standardardised lead investor 's highest level of } \\
\text { education (PhD=4, Master=3, Bachelor=2, Diploma } \\
\& \text { below=1) and number of organisations worked }\end{array}$ \\
\hline Specialised Human Capital & 178 & $2.00 \mathrm{e}-08$ & 2.016 & -2.294 & 10.25 & $\begin{array}{l}\text { Sum standardised number of ventures invested, } \\
\text { ventures founded/co-founded, advisory roles played } \\
\text { by the lead investor }\end{array}$ \\
\hline Reputation & 178 & 65.04 & 107.5 & 0 & 797 & $\begin{array}{l}\text { Number of unique LPs/co-investors who have } \\
\text { invested into the syndicate's deals on AngelList }\end{array}$ \\
\hline $\begin{array}{l}\text { Fundraising Performance of } \\
\text { Lead Investor }\end{array}$ & 178 & 726966 & $1.015 \mathrm{e}+06$ & 0 & $7.000 \mathrm{e}+06$ & $\begin{array}{l}\text { Total amount the lead investor's syndicate backed on } \\
\text { AngelList }\end{array}$ \\
\hline
\end{tabular}


TABLE 2

\section{Correlation matrix}

\begin{tabular}{|l|l|l|l|l|l|l|}
\hline Variable & $\mathbf{1}$ & $\mathbf{2}$ & $\mathbf{3}$ & $\mathbf{4}$ & $\mathbf{5}$ & $\mathbf{6}$ \\
\hline Gender & 1 & & & & & \\
\hline Location & 0.025 & 1 & & & & \\
\hline General Human Capital (Z) & -0.025 & $-0.171^{*}$ & 1 & & & \\
\hline Specialised Human Capital (Z) & 0.086 & -0.002 & 0.083 & 1 & & \\
\hline Reputation (Z) & 0.048 & $0.263^{*}$ & -0.046 & $0.356^{*}$ & 1 & \\
\hline Fundraising Performance of Lead Investor (log) & -0.027 & 0.092 & -0.021 & $0.190^{*}$ & $0.305^{*}$ & 1 \\
\hline
\end{tabular}


TABLE 3

Direct Effects of General Human Capital and Specialised Human Capital on Lead Investors' Fundraising Performance

\begin{tabular}{llllll}
\hline & Model 1 & Model 2 & Model 3 & Model 4 & Model 5 \\
\hline $\begin{array}{lllll}\text { Control variables } \\
\text { Gender }\end{array}$ & -0.443 & -0.445 & -0.699 & -0.709 & -0.751 \\
& $(1.154)$ & $(1.158)$ & $(1.140)$ & $(1.143)$ & $(1.112)$ \\
Location & 0.597 & 0.591 & 0.602 & 0.577 & 0.135 \\
& $(0.483)$ & $(0.491)$ & $(0.475)$ & $(0.483)$ & $(0.489)$ \\
Independent variables & & & & & \\
General Human Capital (Z) & & -0.020 & & -0.074 & -0.048 \\
& & $(0.244)$ & & $(0.241)$ & $(0.235)$ \\
Specialised Human Capital (Z) & & & $0.620^{* *}$ & $0.626^{* *}$ & 0.324 \\
& & & $(0.237)$ & $(0.238)$ & $(0.249)$ \\
Mediator & & & & & \\
Reputation (Z) & & & & & $0.843^{* *}$ \\
& & & & & $(0.257)$ \\
Model statistics & & & & & \\
Constant & $12.36^{* * *}$ & $12.36^{* * *}$ & $12.60^{* * *}$ & $12.62^{* * *}$ & $12.86^{* * *}$ \\
& $(1.142)$ & $(1.147)$ & $(1.127)$ & $(1.132)$ & $(1.104)$ \\
Observations & 178 & 178 & 178 & 178 & 178 \\
$R^{2}$ & 0.009 & 0.009 & 0.047 & 0.047 & 0.104 \\
adj. $R^{2}$ & -0.002 & -0.008 & 0.03 & 0.025 & 0.077 \\
\hline
\end{tabular}

Standard errors in parentheses

${ }^{*} p<0.05,{ }^{* *} p<0.01,{ }^{* * *} p<0.001$ 
TABLE 4

Negative Binomial Regression Results: Effect of Specialised Human Capital on Reputation

\begin{tabular}{|c|c|c|}
\hline Variables & Model 6 & Model 7 \\
\hline \multirow{2}{*}{ Gender } & 0.555 & 0.0803 \\
\hline & $(0.429)$ & $(0.399)$ \\
\hline \multirow{2}{*}{ Location } & $0.894^{* * *}$ & $0.834^{* * *}$ \\
\hline & $(0.179)$ & $(0.164)$ \\
\hline \multirow[t]{2}{*}{ General Human Capital (Z) } & & -0.0384 \\
\hline & & $(0.0843)$ \\
\hline \multirow[t]{2}{*}{ Specialised Human Capital (Z) } & & $0.605^{* * *}$ \\
\hline & & $(0.102)$ \\
\hline \multirow[t]{2}{*}{ Constant } & $3.155^{* * *}$ & $3.486^{* * *}$ \\
\hline & $(0.430)$ & $(0.403)$ \\
\hline Observations & 178 & 178 \\
\hline \multirow{2}{*}{ /lnalpha } & $0.319^{* * *}$ & 0.135 \\
\hline & $(0.0938)$ & $(0.096)$ \\
\hline \multirow[t]{2}{*}{ alpha } & 1.376 & 1.143 \\
\hline & $(0.129)$ & $(0.110)$ \\
\hline Log likelihood & -898.268 & -877.512 \\
\hline (Pseudo) $\mathrm{R}^{2}$ & 0.014 & 0.037 \\
\hline
\end{tabular}

TABLE 5

Mediation Effects of Reputation on Lead Investors' Fundraising Performance 


\begin{tabular}{|l|l|l|l|l|l|l|l|}
\hline Indirect effect & $\mathbf{a}$ & $\mathbf{S E}_{\mathbf{a}}$ & $\mathbf{b}$ & $\mathbf{S E}_{\mathbf{b}}$ & $\mathbf{Z}$ & $\mathbf{c}$ & Effect ratio \\
\hline General human capital & -3.311 & 7.457 & 0.008 & 0.002 & -0.44 & -0.074 & 0.358 \\
\hline Specialised human capital & 38.475 & 7.374 & 0.008 & 0.002 & $2.777^{* * *}$ & 0.626 & 0.492 \\
\hline
\end{tabular}

a: Unstandardised path coefficient from independent variable to the mediator variable.

$\mathrm{SE}_{\mathrm{a}}$ : Standard error of the relationship between the independent variable and the mediator variable.

b: Unstandardised path coefficient from the mediator variable to the dependent variable.

$\mathrm{SE}_{\mathrm{b}}$ : Standard error of the relationship between the mediator variable and the dependent variable.

Z: Sobel test statistic: $\mathrm{Z}=\mathrm{ab} / \sqrt{\left(\left(\mathrm{a}^{2} \mathrm{SE}_{\mathrm{b}}^{2}\right)+\left(\mathrm{b}^{2} \mathrm{SE}_{\mathrm{a}}^{2}\right)\right)}$

c: Unstandardised path coefficient from independent variable to the dependent variable.

Effect ratio $=a b / c$.

${ }^{* * *} p<0.001$

TABLE 6

Robustness Check: Direct Effects of General Human Capital and Specialised Human Capital on Lead Investors' Fundraising Performance

\begin{tabular}{lccccc}
\hline & Model 1 & Model 2 & Model 3 & Model 4 & Model 5 \\
\hline Control variables & & & & & \\
Gender & -0.443 & -0.445 & -0.699 & -0.709 & -0.835 \\
& $(1.154)$ & $(1.158)$ & $(1.140)$ & $(1.143)$ & $(1.134)$ \\
Location & 0.597 & 0.591 & 0.602 & 0.577 & 0.517 \\
& $(0.483)$ & $(0.491)$ & $(0.475)$ & $(0.483)$ & $(0.480)$ \\
Independent variables & & & & &
\end{tabular}


General Human Capital (Z)

$$
\begin{array}{lll}
-0.0195 & -0.0740 & -0.0799
\end{array}
$$

$\begin{array}{lll}(0.244) & (0.241) & (0.239)\end{array}$

Specialised Human Capital (Z)

$$
\begin{array}{lll}
0.620^{* *} & 0.626^{* *} & 0.342 \\
(0.237) & (0.238) & (0.274)
\end{array}
$$

\section{Mediator}

Reputation (Z)

$0.558^{*}$

$(0.274)$

Model statistics

$\begin{array}{llllll}\text { Constant } & 12.36^{* * *} & 12.36^{* * *} & 12.60^{* * *} & 12.62^{* * *} & 12.77^{* * *} \\ & (1.142) & (1.147) & (1.127) & (1.132) & (1.124) \\ & 178 & 178 & 178 & 178 & 178 \\ \text { Observations } & 0.009 & 0.009 & 0.047 & 0.047 & 0.070 \\ R^{2} & -0.002 & -0.008 & 0.030 & 0.025 & 0.043 \\ \text { adj. } R^{2} & & & & & \end{array}$

Standard errors in parentheses

${ }^{*} p<0.05,{ }^{* *} p<0.01,{ }^{* * *} p<0.001$ 
TABLE 7

Robustness Check: Effect of Specialised Human Capital on Reputation

\begin{tabular}{|c|c|c|}
\hline Variables & Model 6 & Model 7 \\
\hline \multirow{2}{*}{ Gender } & 1.042 & 0.630 \\
\hline & $(0.610)$ & $(0.553)$ \\
\hline \multirow{2}{*}{ Location } & 0.139 & 0.160 \\
\hline & $(0.234)$ & $(0.219)$ \\
\hline \multirow[t]{2}{*}{ General Human Capital (Z) } & & 0.00264 \\
\hline & & $(0.103)$ \\
\hline \multirow[t]{2}{*}{ Specialised Human Capital (Z) } & & $0.695^{* * *}$ \\
\hline & & $(0.127)$ \\
\hline \multirow{2}{*}{ Constant } & 0.278 & 0.446 \\
\hline & $(0.601)$ & $(0.545)$ \\
\hline Observations & 178 & 178 \\
\hline \multirow{2}{*}{ /lnalpha } & $0.755^{* * *}$ & $0.437^{* *}$ \\
\hline & $(0.134)$ & $(0.149)$ \\
\hline \multirow[t]{2}{*}{ alpha } & 2.127 & 1.548 \\
\hline & $(0.286)$ & $(0.230)$ \\
\hline Log likelihood & -421.297 & -402.568 \\
\hline (Pseudo) $\mathrm{R}^{2}$ & 0.003 & 0.048 \\
\hline
\end{tabular}

Standard errors in parentheses

${ }^{*} p<0.05,{ }^{* *} p<0.01,{ }^{* * *} p<0.001$ 
REFERENCES 